\section{Nutrient Assimilation in Southern Highbush Blueberry and Implications for the Field}

\author{
Rebecca L. Darnell ${ }^{1}$, Bruno Casamali, and Jeffrey G. Williamson
}

\begin{abstract}
AdDITONAL INDEX wORDs. grafting, iron, nitrogen, soil amendment, Vaccinium arboreum, Vaccinium corymbosum

SUMMARY. Successful blueberry (Vaccinium sp.) cultivation typically requires soils with low $\mathrm{pH}$, high organic matter, readily available iron, and nitrogen $(\mathrm{N})$ in the ammonium form. Growth of blueberry on typical mineral soils (higher $\mathrm{pH}$, low organic matter) is reduced. Although soil $\mathrm{pH}$ effects on nutrient availability and uptake are known, it is unclear if the requirement for low soil $\mathrm{pH}$ in blueberry production is due to effects on nutrient availability/uptake or is a more direct effect of rhizosphere $\mathrm{pH}$ on root function. In addition, it is unclear if the requirement for high organic matter (soil amendments) is related directly to nutrient availability/ uptake. Several studies have examined the use of rootstocks to increase soil adaptation of blueberry and some of these rootstocks have been found to increase plant vigor and yield. In particular, we have investigated whether sparkleberry (Vaccinium arboreum) - a wild blueberry species that is adapted to high $\mathrm{pH}$ and low organic matter soils-could be used as a rootstock for commercial production of blueberry on mineral soils. Our work indicates that both nitrate $\left(\mathrm{NO}_{3}{ }^{-}\right)$and iron $(\mathrm{Fe})$ uptake and assimilation are greater in sparkleberry compared with southern highbush blueberry [SHB (Vaccinium corymbosum interspecific hybrid)]. This is correlated with increased activity of nitrate reductase (NR) and iron chelate reductase, the rate limiting enzymes for $\mathrm{NO}_{3}{ }^{-}$ and $\mathrm{Fe}$ acquisition, respectively. Field studies comparing growth and yield of own-rooted vs. grafted 'Meadowlark' and 'Farthing' SHB in amended vs. nonamended soils are ongoing. In general, own-rooted plants on amended soils exhibit greater growth than own-rooted on nonamended soils, while grafted plants in either soil system exhibit intermediate growth. Yields generally followed this pattern. Our preliminary results suggest that tolerance of SHB to mineral soils is greater when plants are grafted onto sparkleberry than when grown on their own roots. However, growth and yield of grafted plants grown under mineral soil conditions may not equal or exceed that of own-rooted plants grown under optimum soil conditions, at least in the first years after field planting. Longer term studies are necessary to fully evaluate the potential of using sparkleberry and other blueberry species as rootstocks for SHB and northern highbush blueberry ( V. corymbosum).
\end{abstract}

$\mathrm{B}$ lueberry is a high-value specialty crop and production has undergone significant growth in the last several decades, with further increases projected (Strik and Yarborough, 2005). Blueberry has great potential to become a much more important U.S. and global crop because of their high yield potential, long postharvest life as a fresh berry, health benefits, and wide consumer acceptance. However, blueberry production costs are high, constraining sustainability and profitability of the

Horticultural Sciences Department, University of Florida, P.O. Box 110690, Gainesville, FL 32611

This paper was part of the colloquium "Recent Advances in Perennial Berry Crop Nutrition and Directions for Future Research" held 28 July 2014 at the ASHS Annual Conference, Orlando, FL and sponsored by the Viticulture and Small Fruit (VSF) Working Group.

${ }^{1}$ Corresponding author. E-mail: rld@ufl.edu. fresh market industry; thus, increased production efficiency is necessary for continued competitiveness in a global marketplace. Both establishment and maintenance costs are high in blueberry production. Estimates for field preparation and first-year establishment cost average $\approx \$ 10,000 /$ acre for northern highbush blueberry in the Pacific northwestern United States (Eleveld et al., 2005) and as much as $\approx \$ 20,000 /$ acre for SHB in the southeastern United States (Williamson et al., 2012). Blueberry has strict soil requirements for satisfactory growth; this is reflected in the establishment and maintenance costs. Blueberry cultivation is limited to acidic soils, usually with high organic matter, where iron is readily available and ammonium $\left(\mathrm{NH}_{4}{ }^{+}\right)$is the predominant $\mathrm{N}$ form (Erb et al., 1993; Williamson and Lyrene, 1998). Although blueberry can be grown on more typical mineral soils (i.e., higher native $\mathrm{pH}$ and lower organic matter), the soil inputs required to maintain productivity are extensive (Eleveld et al., 2005; Goulart et al., 1995; Korcak, 1986; Williamson et al., 2006). On sandy soils in the southeastern United States, pine bark application costs up to $\$ 6000$ per acre during site preparation. Additional applications are required every 2 to 3 years to maintain plant vigor and productivity, and cost $\approx \$ 4000 /$ acre. Among other things, these modifications lower soil $\mathrm{pH}$ and result in increased iron and $\mathrm{NH}_{4}{ }^{+}$availability. Without these modifications, blueberry exhibits symptoms of iron deficiency (Brown and Draper, 1980), N deficiency, or both, and poor growth (Korcak et al., 1982). However, soil amendments and mulches may immobilize $\mathrm{N}$, requiring higher $\mathrm{N}$ fertilization rates for optimum productivity (Hart et al., 2006; Williamson and Miller, 2009). The effect of soil $\mathrm{pH}$ on blueberry growth has been studied extensively, particularly as it relates to nutrient availability. High soil $\mathrm{pH}$ decreases $\mathrm{NH}_{4}^{+}$concentration due to increased rates of microbial conversion of $\mathrm{NH}_{4}{ }^{+}$to $\mathrm{NO}_{3}{ }^{-}$at soil $\mathrm{pH}$ above 6.0 (Miller and Hawkins, 2007). Since blueberry takes up $\mathrm{NH}_{4}-\mathrm{N}$ more rapidly than $\mathrm{NO}_{3}-\mathrm{N}$ [Fig. I (Merhaut and Darnell, 1995; Poonnachit and Darnell, 2004)], blueberry exhibits lower tissue $\mathrm{N}$ concentrations when fertilized with $\mathrm{NO}_{3}$ $\mathrm{N}$ compared with $\mathrm{NH}_{4}-\mathrm{N}$ (Merhaut and Darnell, 1996). This, in turn, contributes to growth reductions, as containerized SHB grown with $\mathrm{NH}_{4}{ }^{-}$ $\mathrm{N}$ exhibited significantly greater leaf, stem, and whole plant dry weight compared with plants grown with $\mathrm{NO}_{3}-\mathrm{N}$ [Table 1 (Merhaut, 1993; Poonnachit

\begin{tabular}{llll}
\hline $\begin{array}{l}\text { Units } \\
\text { To convert U.S. to SI, } \\
\text { multiply by }\end{array}$ & U.S. unit & SI unit & $\begin{array}{l}\text { To convert SI to U.S., } \\
\text { multiply by }\end{array}$ \\
\hline 0.4047 & $\mathrm{acre}(\mathrm{s})$ & $\mathrm{ha}$ & $2.471 \mathrm{l}$ \\
28.3495 & $\mathrm{oz}$ & $\mathrm{g}$ & 0.0353 \\
1 & $\mathrm{ppm}$ & $\mu \mathrm{g} \cdot \mathrm{g}^{-1}$ & $\mathrm{l}$
\end{tabular}


and Darnell, 2004)]. Limited uptake of $\mathrm{NO}_{3}-\mathrm{N}$ in blueberry has been attributed in part to low activity of NR, the enzyme responsible for reducing $\mathrm{NO}_{3}{ }^{-}$to nitrite. Lack of detectable leaf NR activity and low root NR activity are characteristic of cultivated blueberry species (Claussen and Lenz, 1999; Darnell and Cruz-Huerta, 2011; Darnell and Hiss, 2006; Poonnachit and Darnell, 2004).

High soil $\mathrm{pH}$ also decreases iron availability in the soil and decreases activity of ferric chelate reductase (FCR), the enzyme responsible for cleaving and reducing $\mathrm{Fe}$ in the soil and making it available for plant uptake. The reduction and cleavage of the ferric-chelate at the apoplastic surface of the root epidermis has a $\mathrm{pH}$ optimum of 5.5-6.0 (Bagnaresi and Pupillo, 1995; Cohen et al., 1997). Thus, the $\mathrm{pH}$ of the rhizosphere can have a profound effect on

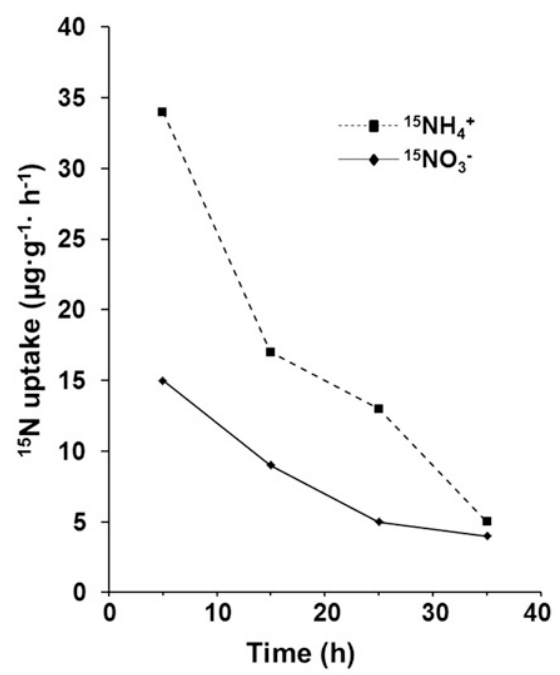
nitrogen $(\mathrm{N})$ uptake on a plant dry weight basis in 'Sharpblue' southern highbush blueberry at intervals following a single application of ${ }^{15} \mathrm{~N}$ labeled ammonium $\left(\mathrm{NH}_{4}{ }^{+}\right)$or ${ }^{15} \mathrm{~N}$ labeled nitrate $\left(\mathrm{NO}_{3}{ }^{-}\right) .1 \mu \mathrm{g} \cdot \mathrm{g}^{-1}=$ 1 ppm (Merhaut and Darnell, 1995).
Fig. 1. Rate of ${ }^{15} \mathrm{~N}$-enriched fertilizer

FCR activity and subsequent ferrous iron uptake.

Although soil $\mathrm{pH}$ effects on nutrient availability and uptake are known, it is unclear if the requirement for low soil $\mathrm{pH}$ in blueberry production is due to effects on nutrient availability/ uptake. Additionally, it is unclear if the requirement for high organic matter (soil amendments) is related directly to nutrient availability/uptake. Regardless of the reasons for the strict soil requirement of cultivated blueberry, the question arises as to whether there are blueberry species that exhibit wider soil adaptation than the cultivated species. If so, there is the possibility of using such species as rootstocks for commercial production to reduce soil inputs.

Sparkleberry is a wild blueberry species native to the southeastern United States (Camp, 1945), which has many characteristics that would be desirable in cultivated blueberry. Sparkleberry has a deep root system and is therefore less susceptible to drought. It grows well on soils with pH 4.5-6.5 (Stockton, 1976), low organic matter (Lyrene, 1997), low $\mathrm{Fe}$ availability, and $\mathrm{N}$ primarily in the $\mathrm{NO}_{3}{ }^{-}$form; i.e., soils that cultivated northern highbush and SHB blueberry tolerate poorly (Lyrene, 1997). In hydroponic systems buffered at $\mathrm{pH}$ 5.5 , sparkleberry exhibits higher rates of NR activity (Fig. 2) and greater rates of $\mathrm{NO}_{3}-\mathrm{N}$ uptake (Fig. 3) compared with SHB (Darnell and CruzHuerta, 201 1; Darnell and Hiss, 2006; Poonnachit and Darnell, 2004). Similarly, FCR activity and Fe uptake are both greater in sparkleberry compared with SHB (Darnell and Cruz-Huerta, 2011), although this is not consistent across all plants within those species (G. Nunez, J.W. Olmstead, and R.L. Darnell, unpublished data).

More recent work indicates that nutrient solution $\mathrm{pH}$ affects $\mathrm{NO}_{3}{ }^{-}$and Fe uptake differently in sparkleberry and SHB (R.L. Darnell, unpublished

Table 1. Dry weight of 'Sharpblue' southern highbush blueberry grown for 16 weeks in sand culture with ammonium $\left(\mathrm{NH}_{4}{ }^{+}\right)$vs. nitrate $\left(\mathrm{NO}_{3}{ }^{-}\right)$nitrogen.

\begin{tabular}{lccccc}
\hline & \multicolumn{5}{c}{ Dry wt $(\mathbf{g})^{\mathrm{z}}$} \\
\cline { 2 - 6 } Treatment & Plant & Shoot & Leaf & Stem & Root \\
\hline $\mathrm{NH}_{4}{ }^{+}$ & $226.3^{\mathrm{y}}$ & 9.0 & $66.6^{\mathrm{y}}$ & $83.4^{\mathrm{y}}$ & 67.2 \\
$\mathrm{NO}_{3}{ }^{-}$ & 167.2 & 9.4 & 36.4 & 64.2 & 52.2 \\
\hline
\end{tabular}

${ }^{\mathrm{z}} 1 \mathrm{~g}=0.0353 \mathrm{oz}$.

yeans are significantly different at $P \leq 0.05$ (Merhaut, 1993). data). Nitrate uptake rate was significantly greater in hydroponically grown sparkleberry at $\mathrm{pH} 7.0$ compared with uptake at $\mathrm{pH} 4.5$ or compared with uptake in $\mathrm{SHB}$ at either $\mathrm{pH}$. The increased $\mathrm{NO}_{3}{ }^{-}$uptake rate correlated with a $20 \%$ to $60 \%$ increase in root NR activity in sparkleberry grown at $\mathrm{pH}$ 7.0. Similarly, there was an increase in both Fe uptake and FCR activity in roots of sparkleberry grown at $\mathrm{pH} 7.0$ compared with sparkleberry grown at

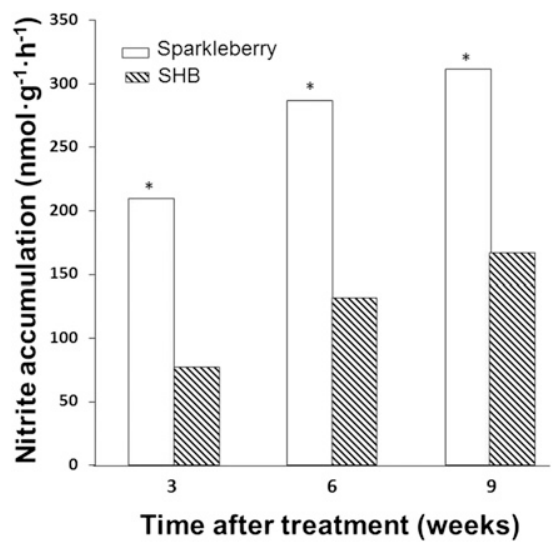

Fig. 2. Root nitrate reductase activity as measured by nitrite accumulation on a root fresh weight basis in hydroponically grown sparkleberry and southern highbush blueberry (SHB). Asterisks indicate significant differences in uptake rate at $P \leq \mathbf{0 . 0 5}$ (modified from Darnell and Hiss, 2006). $1 \mathrm{~g}=\mathbf{0 . 0 3 5 3} \mathrm{oz}$.

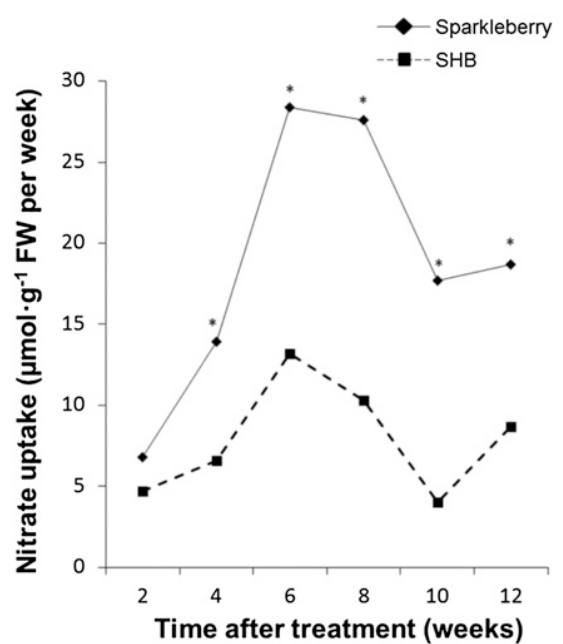

Fig. 3. Nitrate uptake rate in hydroponically grown sparkleberry and southern highbush blueberry $(\mathrm{SHB})$. Asterisks indicate significant differences in uptake rate at $P \leq \mathbf{0 . 0 5}$ (Darnell and Cruz-Huerta, 2011). $1 \mathrm{~g}=$ 0.0353 oz. 
$\mathrm{pH} 4.5$ or $\mathrm{SHB}$ grown at either $\mathrm{pH}$. These preliminary results suggest that both $\mathrm{NO}_{3}{ }^{-}$and $\mathrm{Fe}$ uptake, and assimilation in sparkleberry are greater than in $\mathrm{SHB}$ at higher rhizosphere $\mathrm{pH}$ and may, at least partially, account for why sparkleberry is better adapted to mineral soils than in SHB.

Varying tolerances among blueberry species to high soil $\mathrm{pH}$ and low soil organic matter present possibilities for rootstock use to increase adaptation of blueberries to nontraditional blueberry soils. Galletta and Fish (1971) reported broader adaptation to nontraditional blueberry soils for northern highbush blueberry grafted on rabbiteye blueberry (Vaccinium virgatum) compared with ownrooted northern highbush blueberry, with no indications of graft incompatibility after 7 to 10 years. In general, northern highbush blueberry grafted on rabbiteye blueberry was more vigorous, larger, and had lower mortality rates than own-rooted northern highbush blueberry. Ballington (1998) compared 'Premier' rabbiteye blueberry on its own roots with 'Premier' grafted on sparkleberry for four harvest seasons on a sandy soil with irrigation applied only during the establishment year. For the first harvest, yield of grafted plants was about twice that of own-rooted plants and nearly 2.5 times greater during the subsequent three harvest seasons. In southeastern China, Xu et al. (2014) compared own-rooted 'Sharpblue' SHB with 'Sharpblue' grafted on sea bilberry (Vaccinium bracteatum), a native species known to have a broad ecological adaptation. Grafted 'Sharpblue' had greater yield, plant height, and crown diameter than own-rooted plants for the first 3 years following planting.

Casamali et al. (2013) compared own-rooted 'Meadowlark' and 'Farthing' SHB with the same cultivars grafted onto sparkleberry rootstocks, grown in either pine-bark amended or nonamended soil in two northcentral Florida locations (Citra and Archer). Own-rooted plants in pinebark amended soil had larger canopy volumes than own-rooted plants in nonamended soil, or grafted plants in either soil treatment for both cultivars and both locations following the first complete growing season. The following year (2.5 growing seasons from planting), treatment effects on canopy volume in 'Farthing'
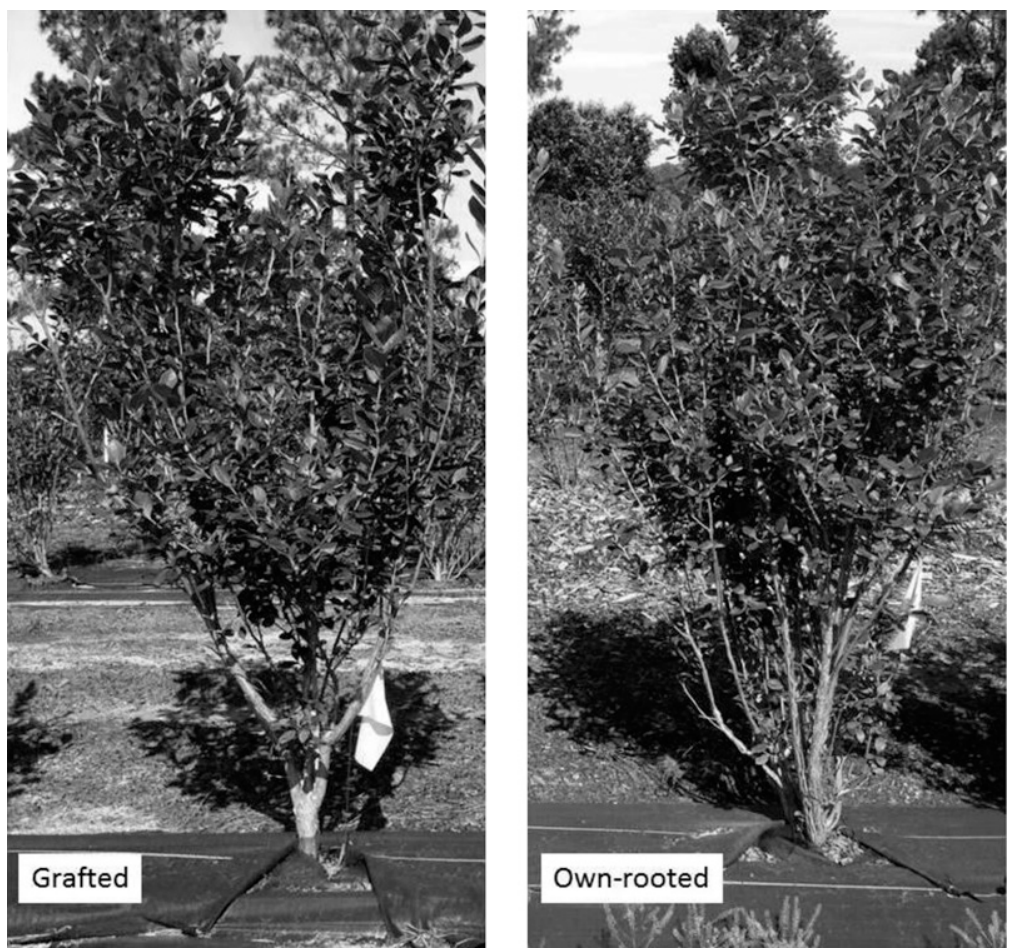

Fig. 4. 'Meadowlark' southern highbush blueberry grafted on sparkleberry (left) and own-rooted (right) growing in amended soil $(\mathrm{pH} \approx 5.0)$ showing similar canopy volumes in July 2013.

were similar to what was observed in the first year (Casamali et al., 2013). However, canopy volumes of grafted 'Meadowlark' on either amended or nonamended soil were the same or slightly smaller than canopy volumes of own-rooted plants on amended soil (Fig. 4). Furthermore, canopy volumes of grafted 'Meadowlark' on nonamended soil were greater than own-rooted plants on nonamended soil (B. Casamali, R.L. Darnell, and J.G. Williamson, unpublished data) and severe chlorosis was observed in own-rooted, but not grafted plants, of both cultivars in nonamended soil (Fig. 5).

During the first fruiting year, own-rooted plants in amended soil produced the greatest yields for both cultivars (Casamali et al., 2013). However, during the second fruiting year, grafted 'Meadowlark' produced greater yields than own-rooted 'Meadowlark' at Citra, while at the Archer location, the greatest yields were obtained in both cultivars grown on their own roots in amended soil followed by grafted plants in either soil type, and own-rooted plants on nonamended soil (B. Casamali, R.L. Darnell, and J.G. Williamson, unpublished data).
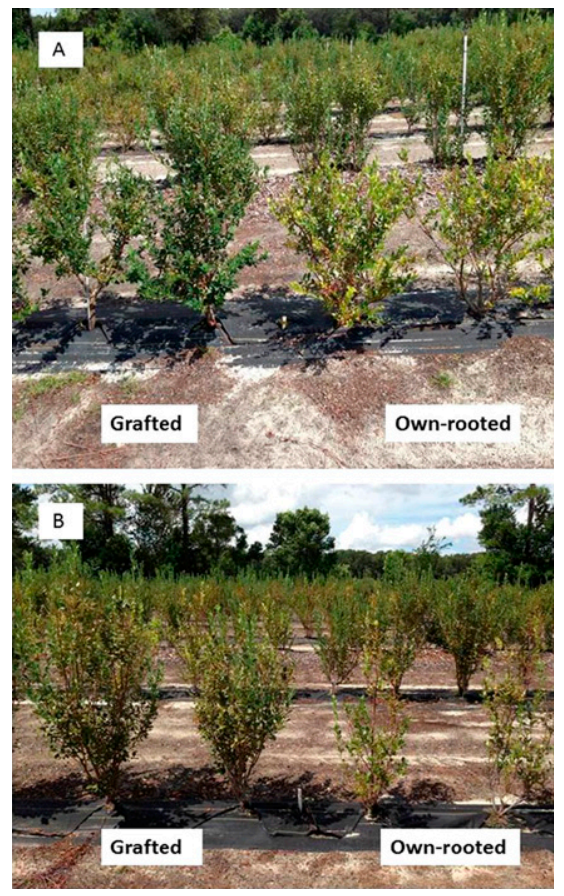

Fig. 5. 'Meadowlark' (A) and

'Farthing' (B) southern highbush blueberry grafted on sparkleberry (left) and own-rooted (right) growing in nonamended soil $(\mathrm{pH} \approx 6.0)$. Ownrooted plants of both cultivars are smaller and exhibit leaf chlorosis compared with grafted plants. 
Certain blueberry species, including sparkleberry, may have potential as rootstocks for northern highbush and SHB blueberry to expand commercial blueberry production into soils that are currently considered unsuitable (i.e., high soil $\mathrm{pH}$ and low soil organic matter). Further, the use of rootstocks may increase the productivity and longevity of blueberry plantings, especially under marginal soil conditions. Generally, tolerance of northern and SHB blueberry to adverse soil conditions such as high soil $\mathrm{pH}$ and low organic matter appears to be substantially greater when plants are grafted on certain blueberry species than when grown on their own roots. However, it is unclear whether size, vigor, and yield of grafted plants grown under adverse soil conditions will equal or exceed that of own-rooted plants grown under optimum soil conditions. Furthermore, scion by rootstock interactions were noted for northern highbush blueberry grafted on rabbiteye blueberry (Galletta and Fish, 1971) and SHB grafted on sparkleberry (Casamali et al., 2013), indicating a need for additional long-term evaluations of a range of blueberry cultivars on a variety of rootstock species.

\section{Literature cited}

Bagnaresi, P. and P. Pupillo. 1995. Characterization of NADH-dependent $\mathrm{Fe}^{3+}$-chelate reductases of maize roots. J. Expt. Bot. 46:1497-1503.

Ballington, J.R. 1998. Perfomance of own-rooted 'Premier' rabbiteye blueberry (Vaccinium ashei Reade) compared to 'Premier' grafted on Vaccinium arboreum March (sparkleberry) over four harvest season. Proc. 8th North Amer. Blueberry Res. Ext. Workers' Conf. 178-181.

Brown, J.C. and A.D. Draper. 1980. Differential response of blueberry (Vaccinium) progenies to $\mathrm{pH}$ and subsequent use of iron. J. Amer. Soc. Hort. Sci. 105:20-24.

Camp, W.H. 1945. The North American blueberries with notes on other groups of Vacciniaceae. Brittonia 5:203-275.

Casamali, B., R.L. Darnell, and J.G. Williamson. 2013. Vaccinium arboreum: A rootstock for southern highbush blueberry? HortScience 48:S279 (Abstr.).

Claussen, W. and F. Lenz. 1999. Effect of ammonium or nitrate nutrition on net photosynthesis, growth, and activity of the enzymes nitrate reductase and glutamine synthetase in blueberry, raspberry, and strawberry. Plant Soil 208:95-102.

Cohen, C.K., W.A. Norvell, and L.V. Kochian. 1997. Induction of the root cell plasma membrane ferric reductase: An exclusive role for $\mathrm{Fe}$ and $\mathrm{Cu}$. Plant Physiol. 114:1061-1069.

Darnell, R.L. and N. Cruz-Huerta. 2011. Uptake and assimilation of nitrate and iron in cultivated and wild Vaccinium species. Intl. J. Fruit Sci. 11:136-150.

Darnell, R.L. and S. Hiss. 2006. Uptake and assimilation of nitrate and iron in two Vaccinium species as affected by external nitrate concentration. J. Amer. Soc. Hort. Sci. 131:5-10.

Eleveld, B., B. Strik, K. DeVries, and W. Yang. 2005. Blueberry economics: The costs of establishing and producing blueberries in the Willamette Valley. Oregon State Ext. Serv. EM 8526:41.

Erb, W.A., A.D. Draper, and H.J. Swartz. 1993. Relation between moisture stress and mineral soil tolerance in blueberries. J. Amer. Soc. Hort. Sci. 118:130-134.

Galletta, G.J. and A.S. Fish, Jr. 1971. Interspecific blueberry grafting, a way to extend Vaccinium culture to different soils. J. Amer. Soc. Hort. Sci. 96:294298.

Goulart, B.L., K. Demchak, and W.Q. Yang. 1995. Organic matter and nitrogen level effects on mycorrizal infection in 'Bluecrop' highbush blueberry plants. J. Small Fruits Viticult. 3:151-164.

Hart, J., B. Strik, L. White, and W. Yang. 2006. Nutrient management for blueberries in Oregon. Oregon State Ext. Serv. EM 8918:14.

Korcak, R.F. 1986. Adaptability of blueberry species to various soil types. I. Growth and initial fruiting. J. Amer. Soc. Hort. Sci. 111:816-821.

Korcak, R.F., G.J. Galletta, and D.A. Draper. 1982. Response of blueberry seedlings to a range of soil types. J. Amer. Soc. Hort. Sci. 107:1153-1160.

Lyrene, P.M. 1997. Value of various taxa in breeding tetraploid blueberries in Florida. Euphytica 94:15-22.

Merhaut, D.J. 1993. Effects of nitrogen form on vegetative growth, and carbon/ nitrogen assimilation, metabolism, and partitioning in blueberry. Univ. Florida, Gainesville, PhD Diss. No. 9505801.
Merhaut, D. and R. Darnell. 1995. Ammonium and nitrate accumulation in containerized southern highbush blueberry plants. HortScience 30:1378-1381.

Merhaut, D. and R. Darnell. 1996. Vegetative growth and nitrogen/carbon partitioning in blueberry as influenced by nitrogen fertilization. J. Amer. Soc. Hort. Sci. 121:875-879.

Miller, B.D. and B.J. Hawkins. 2007. Ammonium and nitrate uptake, nitrogen productivity and biomass allocation in interior spruce families with contrasting growth rates and mineral nutrient preconditioning. Tree Physiol. 27:901-909.

Poonnachit, U. and R. Darnell. 2004. Effects of ammonium and nitrate on ferric chelate reductase and nitrate reductase in Vaccinium species. Ann. Bot. (Lond.) 93:399-405.

Stockton, L.A. 1976. Propagation and autecology of Vaccinium arboreum and its graft compatibility with Vaccinium ashei. Texas A\&M Univ., College Station, MS Thesis.

Strik, B.C. and D. Yarborough. 2005. Blueberry production trends in North America, 1992 to 2003, and predictions for growth. HortTechnology 15:391398.

Williamson, J.G., G. Krewer, G. Pavlis, and C.M. Mainland. 2006. Blueberry soil management, nutrition and irrigation, p. 60-74. In: N.F. Childers and P.M. Lyrene (eds.). Blueberries, for gardeners, growers, and promoters. Childers Hort. Publ., Gainesville, FL.

Williamson, J.W. and P.M. Lyrene. 1998. Florida's commercial blueberry industry. Inst. Food Agr. Sci., Univ. Florida, Publ. HS 742 .

Williamson, J.W. and P. Miller. 2009. Effects of fertilizer rate and form on vegetative growth and yield of southern highbush blueberry in pine bark culture. HortTechnology 19:152-157.

Williamson, J.G., J.W. Olmstead, and P.M. Lyrene. 2012. Florida's Commercial Blueberry Industry. 25 Jan. 2015. $<$ https://edis.ifas.ufl.edu/pdffiles/AC/ AC03100.pdfs.

Xu, C., Y. Ma, and H. Chen. 2014. Technique of grafting with Wufanshu (Vaccininm bracteatum Thumb.) and the effects on blueberry plant growth and development, fruit yield and quality. Sci. Hort. 176:290296. 